\title{
ImPaCt OF Predation by CATtle EGRET BUBULCUS IBIS L. ON WILDLIFE of FARMLANDS IN ChLEF REgion, AlgERIA
}

\author{
A. Mohammedi, S. Doumandji ${ }^{1}$, A. Ababou, M. Koudjil and A. Rouabhi \\ Laboratory of production and plant protection, Institute of agricultural sciences, Université \\ Hassiba Ben Bouali, Chlef, Algeria \\ ${ }^{1}$ Higher national school of agronomy (ENSA), Algiers, Algeria \\ mohham_ahmed@yahoo.fr
}

(Received 1 December 2015 - Accepted 16 September 2016)

\section{ABSTRACT}

Mohamedi, A., S. Doumandji, A. Ababou, M. Koudjil, and a. Rouabhi. 2016. Impact of predation by cattle egret Bubul ibiscus ibis $L$. on wildlife of farmlands in Chlef region of Algeria. Lebanese Science Journal, 17(2): 117- 129.

The study was conducted in the region of Chlef which is located approximately at $200 \mathrm{~km}$ North-West of Algiers and at 36 $12^{\prime}$ North latitude and $1^{\circ} 19^{\prime}$ East longitude. The objective of this study was to evaluate the impact of predation of Cattle Egret on crop pests in four different agricultural areas of the region (cereal, potato, citrus orchard and uncultivated field), from the comparison between preys consumed by the predator and the potential preys available in these environments.Trappings of preys made in the area studied have revealed that the abundance of potential preys differs from one habitat to another, although not exploited environment is richer than the others. The calculation of the diversity with the index of Shannon-Wiever and the similarity with the index of community of Jaccard have shown that the preys consumed by the cattle egret are only partly similar to the set of potential preys. It is possible that this bird looks for its preys in other areas different from those surveyed. The calculation of attendance of agricultural environments by the Cattle Egret showed that this bird is very opportunistic; it uses these areas in a well-planned manner, depending on the availability of preys. Thus, the impact of its predation on wildlife and especially the insect fauna of different agricultural habitats, although it differs from one medium to another, remains important and beneficial to local culture.

Keywords: Cattle Egret, Agriculture, impact, pest, predator.

\section{INTRODUCTION}

The Cattle Egret, of African origin (Siegfried, 1978; Franchimont, 1986; Arendt, 1998; Abulude et al., 2005; Joshi and Shrivastava, 2012) has extended its area of expansion in the world since the early 20th century (Lowe et al., 1994; McKilligan, 2005).

http://dx.doi.org/10.22453/LSJ-017.2.117129

National Council for Scientific Research - Lebanon 2016@

lsj.cnrs.edu.lb/vol-17-no-2-2016/ 
Many studies have been conducted worldwide on the diet of this species (Duxbury, 1963; Siegfried, 1966 and 1971; Burns and Chapin, 1969; Fogarty and Hetrick, 1973; Jenni, 1973; Ruiz and Jover, 1981; Bredin, 1984; Scott, 1984; McKilligan, 1984; Ruiz, 1985; Fujoka, 1985; Franchimont, 1986; Parasharya et al., 1994; Lombardini et al., 2001; Seedikkoya et al., 2007; Sharah et al., 2008). In Algeria, the diet of B. ibis was studied by Doumandji et al. (1992 and 1993), Setbel et al. (2004), Boukhemza et al.(2000), Si Bachir et al. (2001), Salmi et al. (2002), Boukhemza et al. (2004) and Mohammedi and Doumandji (2013). All these studies showed that this species is primarily insectivorous, but can also feed on invertebrates, fish, amphibians, eggs and nestlings of birds, and mammals.

These preys are sought especially in the farmland where Cattle Egret was considered as important biological control agent (Sharah et al., 2008). Plant pests represent $78.34 \%$ of its prey in the Chlef region in Algeria (Mohammedi and Doumandji, 2013) and $88.7 \%$ in an arid area in Nigeria (Sharah et al., 2008). These birds travel, daily several agroecosystems in search of preys, but no study to date, at least in Algeria, has highlighted the impact of the diet of this predator species on potential preys farmland, hence the purpose of this study.

\section{METHODOLOGY}

The study was conducted in the region of Chlef, which is located approximately at $200 \mathrm{~km}$ North- West of Algiers and $36^{\circ} 12^{\prime}$ North latitude and $1^{\circ} 19^{\prime}$ longitude east.

In order to study the relationship of preys consumed by the Cattle Egret and their availability in the agricultural community of the Chlef region, we have chosen four different agricultural habitats : an uncultivated medium (wasteland), a cereal medium (durum wheat), a market gardening medium (potato field), and an arboreal medium (citrus orchard). In each environment, we made an inventory of the fauna present, which can potentially represent the preys of the Cattle Egret using traps Barber (pitfall traps). In each field, we set up six traps according to a regular triangle with a perimeter of $180 \mathrm{~m}$, on each vertex is deposited a black trap and in the middle of each side is deposited a yellow trap, the traps are distanced from each other by $30 \mathrm{~m}$. However, the yellow traps attract flying and heliophilous insects and, whereas the black traps are efficient for walkers' insects, accustomed to take refuge in the crevices and litter (Roth, 1972). The preys consumed by the Cattle Egret are determined each month by an analysis of 10 pellets regurgitated by adults. These are collected from a heronry located in a public garden in the city of Chlef, a total of 120 pellets were examined. This method does not necessitate the killing of birds. To study the attendance of agricultural environments by Cattle Egrets, we performed a monthly count of birds in each environment. When the number is large and the distribution of Cattle Egret is more or less homogeneous, we proceed to count the number of individuals per unit area $(20 \mathrm{~m} \times 20 \mathrm{~m})$ and then proceed to estimate the number according to the surface area occupied by the birds.

The frequency in number of each class of preys was calculated based on the total number of consumed preys by the Cattle Egrets (Dajoz, 1985). The diversity index of Shannon- Weaver is calculated as follows:

$\mathrm{H}=-\mathrm{Pi} \Sigma \mathrm{i}(\log \mathrm{P})$, where $\mathrm{Pi}$ is the proportion of the total number of individuals that were counted in a case or class of a given prey (Frontier, 1983), while the index of equitability also 
called index of equal distribution is the ratio of the Shannon index on theoretical maximum index $(\mathrm{E}=\mathrm{H} / \mathrm{Hmax}$ and $\mathrm{Hmax}=\log \mathrm{S}$ ( $\mathrm{S}$ is the number of species) (Blondel, 1979).

To study the similarities between the potential preys of different agro ecosystems, on one hand, and between these potential preys and those actually consumed by Cattle Egret on the other hand, we calculated the Jaccard index of community similarity. For this we used the formula $S=[w /(A+B-w)]$, where $w$ is the abundance of species sharing the two sites, $\mathrm{A}$ is the abundance of species in the medium 1, while $\mathrm{B}$ is the abundance of species in medium B (Spellerberg, 1993).

\section{RESULTS}

\section{Potential preys and preys consumed by Cattle Egret}

Trapping methods implemented revealed that the uncultivated field is the richest in potential preys ( 951 individuals), followed by citrus orchard (835 individuals), then the cereal field (748 individuals) and in the last position the potato field (487 individuals) (Table 1). Insects dominate potential preys and also those found in the pellets of the Cattle Egret with frequencies ranging from $95.48 \%$ to $98.42 \%$. These are in turn dominated by Coleoptera and Orthoptera. Among the preys consumed, the arachnids are in second position (2.55\%). These were found in the citrus orchard and in the uncultivated field. The Mammals, although they have not been encountered in the surveyed areas, represent $1.13 \%$ of the preys of Cattle Egret. The Gastropods, Reptilia and Amphibia are also consumed, but at very low rate, not exceeding $0.14 \%$, although the first group is present only in the cereal medium and in the market gardening medium, the second group in the citrus orchard and the third group in the uncultivated field. The Crustacea, represented by Isopods are present among potential preys of cereal environment but absent in the diet of the Heron.

TABLE 1

Number and (Frequency) of Potential Preys and those Consumed by Cattle Egret

\begin{tabular}{|l|l|l|l|l|l|l|}
\hline Classes & Orders & P. C & P. P.C & P.P.P & P.P.O & P.P.U \\
\hline Insecta & & $\mathbf{3 3 0 8}(\mathbf{9 5 , 7 4 )}$ & $\mathbf{7 1 5}(\mathbf{9 5 , 5 9 )}$ & $\mathbf{4 6 5}(\mathbf{9 5 , 4 8})$ & $\mathbf{8 0 3}(\mathbf{9 6 , 1 7})$ & $\mathbf{9 3 6}(\mathbf{9 8 , 4 2})$ \\
& Coleoptera & 1623 & 260 & 121 & 136 & 308 \\
& Orthoptera & 784 & 316 & 155 & 102 & 320 \\
& Mantoptera & 32 & 5 & - & 15 & 9 \\
& Dermaptera & 13 & - & - & 23 & 18 \\
& Hemiptera & 427 & 80 & 24 & 120 & 69 \\
& Homoptera & 35 & 8 & 60 & 216 & - \\
& Hymenoptera & 340 & 25 & 44 & 69 & 102 \\
\hline
\end{tabular}




\begin{tabular}{|c|c|c|c|c|c|c|}
\hline & Diptera & 54 & 12 & 33 & 58 & 76 \\
\hline & Lepidoptera & - & 9 & 28 & 64 & 34 \\
\hline \multirow[t]{3}{*}{ Arachnida } & - & $88(2,55)$ & - & - & $17(2,03)$ & $2(0,21)$ \\
\hline & Aranea & 58 & - & - & 17 & 1 \\
\hline & Opiliones & 30 & - & - & - & 1 \\
\hline \multirow[t]{3}{*}{ Myriapoda } & - & $11(0,32)$ & - & - & $12(1,44)$ & - \\
\hline & Chilopoda & 7 & - & - & 9 & - \\
\hline & Diplopoda & 4 & - & - & 3 & - \\
\hline Crustacea & Isopoda & - & $17(2,27)$ & - & - & - \\
\hline Gastropoda & Pulmonata & $5(0,14)$ & $9(1,2)$ & $12(2,46)$ & - & - \\
\hline Oligocheta & Haplotaxidea & - & $7(0,94)$ & $10(2,05)$ & - & $11(1,16)$ \\
\hline Reptilia & Sauria & $3(0,08)$ & - & - & $3(0,36)$ & - \\
\hline Amphibia & Anura & $1(0,02)$ & - & - & - & $2(0,21)$ \\
\hline Mammalia & Rodentia & $39(1,13)$ & - & - & - & - \\
\hline \multicolumn{2}{|l|}{ TOTAL } & 3455 & 748 & 487 & 835 & 951 \\
\hline
\end{tabular}

$\mathrm{P} . \mathrm{C}=$ prey consumed, $\mathrm{PPC}=$ potential preys of the cereal field, $\mathrm{PPP}=$ potential preys of potato field, $\mathrm{PPO}=$ potential preys of the citrus orchard, $\mathrm{PPU}=$ potential preys of uncultivated field.

Diversity of the potential preys and those consumed by Cattle Egret.

The values of the diversity index of Shannon-Weaver and those of equitability calculated for potential preys show that uncultivated field is the most diverse $(\mathrm{H}=4.26$ bits, $\mathrm{E}$ $=0.92)$, followed by the cereal medium $(\mathrm{H}=2.95$ bits, $\mathrm{E}=0.7)$, then the citrus orchard in third position $(\mathrm{H}=2.38$ bits, $\mathrm{E}=0.55)$ (Table 2). On the other hand the least diverse environment is the potato field $(\mathrm{H}=1.72$ bits, $\mathrm{E}=0.48)$. The preys consumed by the Heron are much more diverse than potential preys present in the farmland, as they have an index of 4.56 bits and an equitability of 0.95 . 
TABLE 2

The Values of the Shannon- Weaver Diversity Index and those of Equitability Calculated for Potential Preys and those Consumed by Cattle Egret

\begin{tabular}{|c|c|c|c|c|c|}
\hline Parameters & $\begin{array}{c}\text { p.p.cereal } \\
\text { field }\end{array}$ & $\begin{array}{c}\text { p.p.potato } \\
\text { field }\end{array}$ & $\begin{array}{c}\text { p.p.citrus } \\
\text { orchard }\end{array}$ & $\begin{array}{c}\text { p.p.uncultivated } \\
\text { field }\end{array}$ & $\begin{array}{c}\text { preys } \\
\text { consumed }\end{array}$ \\
\hline H(bits) & 2.95 & 1.72 & 2.38 & 4.26 & 4.56 \\
Hmax & 4.18 & 3.58 & 4.34 & 4.63 & 4.8 \\
E & 0.7 & 0.48 & 0.55 & 0.92 & 0.95 \\
\hline
\end{tabular}

\section{Similitude between potential preys and those consumed by Cattle Egret}

The values of the Jaccard index calculated for potential preys encountered in four agricultural areas surveyed and those consumed by Cattle Egret, show that the highest similarity was observed between all the preys of Cattle Egret and the pests preys $(0,78)$, this demonstrate that most preys of Cattle Egret are pests (Table 3). The preys consumed by this bird show a similarity of 0.29 with all potential preys and 0.13 with those of cereal medium and the uncultivated medium, unlike arboreal habitats and potato field which harbor a wildlife that is of low similarity $(0,05$ and 0.07$)$ than that found in the pellets of Heron. All potential preys are most similar to the fauna of the uncultivated crop (0.35) than other media. As for similarities calculated between the four agricultural environments, the higher is noted between the uncultivated field and the cereal medium (0.31).

TABLE 3

The values of the Jaccard index calculated between potential preys and those consumed by Cattle Egret

\begin{tabular}{|l|l|l|l|l|l|l|l|l|}
\hline Prey & P. C & H.P.C & BPC & P. P & P. P.C & P. P.P & P. P.O. & P. P.U \\
\hline P. C & & $\mathbf{0 , 7 8}$ & 0,18 & $\mathbf{0 , 2 9}$ & $\mathbf{0 , 1 3}$ & $\mathbf{0 , 0 7}$ & $\mathbf{0 , 0 5}$ & $\mathbf{0 , 1 3}$ \\
P.C.D & & & 00 & 0,24 & $\mathbf{0 , 1 3}$ & 0,06 & 0,04 & $\mathbf{0 , 1 2}$ \\
P.C.U & & & & 0,09 & 0,07 & 0,05 & 0,07 & 0,06 \\
P. P & & & & & 0,25 & 0,16 & 0,28 & $\mathbf{0 , 3 5}$ \\
P. P.C & & & & & & 0,18 & 0,13 & $\mathbf{0 , 3 1}$ \\
P. P.Pt & & & & & & 0,14 & 0,18 \\
P.P.Ag & & & & & & & 0,23 \\
P. P.F & & & & & & \\
\hline
\end{tabular}

consumed, PP: Potential prey, $\mathrm{PPC}=$ Potential prey of cereal field, $\mathrm{PPP}=$ Potential prey of potato field, $\mathrm{PPCt}=$ Potential prey of citrus orchard eld, $\mathrm{PPU}=$ Potential prey of uncultivated field. 


\section{Frequency of utilization of agricultural environments by Cattle Egret}

The study of the use of farmland by the Cattle Egret to search for preys showed that the frequency of use varies from one month to another, sometimes from one season to another, depending on the food availability. In general, the cereal medium and uncultivated environment seem to be the most frequented by population of Cattle Egret. Indeed, the attendance rate of uncultivated fields was high during the period from January to May, though it is in March and April, that this medium was most visited (50\% in March and 62\% in April). The cereal medium was busiest during the period of May-July (45\% in May, $48 \%$ in June and $38 \%$ in July) and also in October $(60 \%)$ and November $(55 \%)$. In the potato fields, the presence of Cattle Egret was observed only during periods of plantation or harvest. These correspond to January (45\%) and February (55\%), June (37\%) and August (39\%) and also in November (31\%) and December (29\%). The arboreal field does not seem to be preferred as well as other settings; however, the highest rates were recorded in March and April with $37 \%$ and $29 \%$ respectively and that from July to September with rates ranging from $22 \%$ to $29 \%$. tasty.

\section{DISCUSSION}

The abundance of animal populations in ecosystems varies depending on the requirements of the animal species and conditions offered by the medium. However the trappings made in media studies revealed that the uncultivated fields offers more potential preys to predatory birds, especially Bubulcus ibis, that the other groups, although the cereal and arboreal environments are also rich in preys, unlike the potato field where abundance of this fauna is halved (Figure 1). This is probably due to the nature of agricultural works made

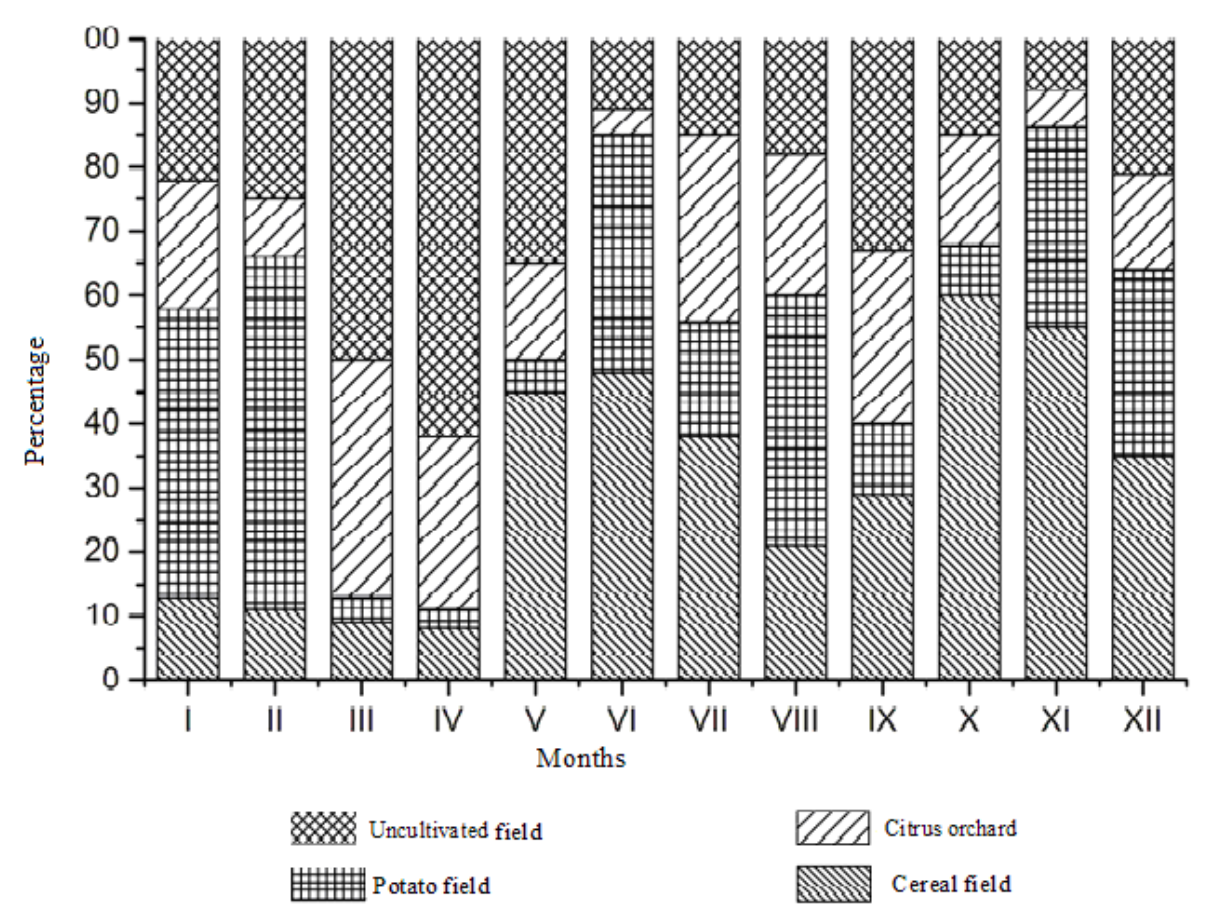

Fig 1: Percentage of individuals observed in each environment during different months of the year 
in each culture. Cusson (2006) pointed out that many animals need open areas, an herbaceous or shrub cover developed as wasteland to find preys that are present in this environment.

Both potential preys taken from the four environments studied and those collected from the pellets of the Cattle Egret are dominated by insects. This has already been noted in different regions of Algeria by several authors as Boukhemza et al. (2004); Salmi et al. (2002); Setbel et al. (2004) and Filali and Doumandji (2007). Even in the southern of Deux-Sèvres in France, the importance of insects was observed in intensive cereal with a frequency of $93.6 \%$ (Clere and Bretagnolle, 2001).

The dominance of insect among the preys of Cattle Egret was mentioned in all the previous work carried out on the diet of this species, whether in Algeria or elsewhere. Sometimes it is close to $100 \%$. In Algeria, it is the case of the Kabylie region (Si Bachir et al., 2001) and Draa El Mizan (Doumandji et al., 1993). Moreover, this rate reached $95.8 \%$ of insects in Japan (Ikeda, 1956), 89.1\% in Louisiana (Chapin, 1969), 80\% in South Africa (Siegfried , 1971), $89.3 \%$ in Mexico ( Torres Vasquez and Marquez Mayaudon, 1972) , $90 \%$ in Florida (Fogarty and Hetrick, 1973) and 68.4\% in the Delta El Ebro in Spain (Ruiz and Jover, 1981). The presence of insect preys in the digestive tract whether by the proportion, weight or volume is related to its relative abundance in the ecosystem where Cattle Egrets feed (Sharah et al., 2008).

The consumption rate of animals other than insects varies in time and space. However, the mammals whose consumption is very significant in our study area are less mentioned in other regions such as Mitidja in Algeria (Setbel, 2008). Also, the amphibians which are generally rare in the dry season, are noted extensively in the diet of the Cattle Egret in the Camargue (Hafner, 1980), in Spain (Ruiz, 1985; Ruiz and Jover, 1981) and Florida (Jenni, 1969 and 1973). Yet they are not widely consumed in our region and also in Mitidja (Setbel, 2008). Finally, centipedes are moderately consumed in Chlef and rarely mentioned elsewhere, among the preys of the Cattle Egret.

The diversity of preys consumed by the Cattle Egret is close to those of potential preys found in the cereal and the uncultivated fields, rather than that of the other two fields. This means that the largest number of preys, whether in species or in individuals, were captured in these two environments. Agriculture has effects on changes in biodiversity. Agricultural practices are at the heart of the mechanism that have an impact on the diversity of species and landscapes (Bersonnet et al., 2009). Accordingly, the values of diversity are much higher in the undisturbed medium (area) that is natural and heterogeneous. Clere and Bretagnolle (2001) found for the insects, the values of $\mathrm{H}^{\prime}$ are ranging from 1.12 bits in a cereal field (disturbed habitats) to 3.41 bits in a fallow area (less disturbed habitat). Sometimes, the evolution of farming also contributes to the increase of richness; it creates and maintains ecosystems and habitats. Thus, the mosaic of cultivated fields separated by hedges and ditches provides the resource to certain types of flora and microfauna, it is also, a wintering location for many insects, buffer zones against wind and water erosion, or even denitrification zones (Debras et al., 2007). It is noted that the diversity of preys consumed by the Cattle Egret varies from one month to another Doumandji et al., (1993) and also from a pellet to another (Setbel, 2008). The seasonal changes affect insect preys' populations. This also affects feeding behavior and ecology of Cattle Egrets that cause them to change their ecosystem (Sharah et al., 2008). Siegfried (1971) reported a similar situation when $85 \%$ of the gut contents of Cattle Egrets are worms in winter, but none were found during the summer 
periods. Indeed, the use of feeding sites by Cattle Egrets depends on several factors. Some are linked to the species, including life cycle stages whose requirements differ from one stage to another. However, during the period of breeding, the number increases because adults of Cattle Egret show a greater feeding because their trophic activity needs and those of their offspring increase (Seedikkoya et al., 2005; Shara et al, 2008). Others are related to the environment, including the availability of prey and water, the location of the environment and vegetation cover (SCOTT, 1984).

A great similarity was found between all the consumed preys by the Cattle Egret and the potential preys which are pests, this means that the preys of Cattle Egret consist mainly of crop pests, both in terms of specific richness and of abundance, in contrast to useful preys which have low similarity to all the preys; The heronry studied is located in the plain region of Cheliff which is constituted entirely or almost entirely of agricultural plots. These undergo periodic soil works and also phytosanitary treatments whose impact on non-target fauna has been reported by several authors (Benton et al., 2003; Frouz, 1999).

The Potential preys and those consumed by the Cattle Egret are only slightly similar. Consequently, it appears that this bird seek its preys in other areas different from those surveyed. In fact, Cattle Egret is cited as a semi aquatic bird in certain regions as in India, where he is frequently mentioned in wetlands such as fresh waters and paddy fields (Joshi and Shrivastava, 2012) and essentially as land bird in others as in Nigeria where he frequented alot more arid environments (Shara et al., 2008). This Egret frequents mainly the marsh, the degraded scrubland, the rubbish dumps, the plowed fields, the low crops, the temporary ponds, the lowlands, the deltas or wide valleys, where this predator enjoys abundant resources throughout the year, as it frequents also meadows, woodlands and wetlands (Etchecopar and Hue, 1964; Dorst, 1971; Voisin, 1979 and 1991; Franchimont, 1986; Doumandji et al., 1988). This does not exclude the exploration of arid hills when they are traversed by livestock (Geroudet, 1978; Sharah et al., 2008). This species frequent less other habitats as the gardens near urban areas and the banks of streams (Craufurd, 1965). These are frequented only for water supply (Franchimont, 1986). They also use nonagricultural environments such as waste dumps (Seedikkoya et al., 2007). (Frederick \& Mc Gehee, 1994) also pointed the use of landfills and purification ponds of water by this species.

The similarity index also showed that the preys consumed by the Cattle Egret are more similar to the fauna of the cereal and uncultivated plots than the other two environments. Thus, the nature of the vegetation, in whole herbaceous promotes the multiplication of epigeal arthropods which are the preferred preys of this species whose capture is relatively easier. the potential preys found in the study area are more similar to these inventoried in the uncultivated land, a little less than those found in cereal field and citrus orchard; and a little less compared to that of potato field, yet it was cited as an important agent in the regulation of populations of white grubs (Parasharya et al., 1994). The Fallow plots clearly appear as elements of the landscape favorable to the development and maintenance of high biodiversity in agroecosystems, both for the rare and banal species and both for neutral and auxiliary species for crops. Just as orchards, which constitute perennial backgrounds, the plant diversity is mainly due to the creation of facilities of plants within the field (vegetation cover) or on the edge (hurdles). The presence of several strata exploited by biological communities (spatial aspect) and their continuation (temporal aspect) is a situation potentially conducive to the maintenance of food webs and animal diversity. In contrast, in fields, the cultural practices, in particular, the use of pesticides do not allow to maintain a natural balance in the environment, 
therefore, the faunal population decreased, which could justify this dissimilarity with potential preys inventoried in the study area.

The calculation of rates of attendance of agricultural environments by the Cattle Egret showed that this bird is very opportunistic, it uses the plot of cereal during the harvest and plowing where the birds take advantage of the passage of agricultural machines, which, on one hand, disturb the preys by making them visible and easy to capture and on the other hand, live animals in the soil are brought to the surface and made available to predators. This is the case of plot of potato that was used especially during the planting and harvesting. The Cattle Egrets associated with Cattle and machinery capture preys at a significantly higher rate and spend less energy in the process (Heatwole, 1965; Grubb, 1976; Seedikkoya et al., 2005).

The arboreal environment is not appreciated in the same way as the other environments, however, the number of birds visiting this medium is often below those observed elsewhere. It seems that the Herons use the orchards in the summer to avoid high temperatures which are often close to $40^{\circ} \mathrm{c}$. These inhibit the activities of animal preys and make them difficult to capture. The attendance rate of uncultivated areas is high throughout the year, although the highest rates are recorded during the period from January to May. Sharah et al., (2008) noted that these birds do not have predilection for agrosystems in the process of searching for food, as they are present all over the world in different weather conditions, but the distribution of preys in ecosystems is the reason why feed environment are used depending on what they can offer as potential preys. The spatiotemporal variation of utilization of feed environments was mentioned by several authors in different regions of the world, Siegfried (1971). Sharah et al. (2008) and Fasola et al. (2010) reported a marked seasonal variation in habitats used by Herons. However, the grass fields followed by plans of shallow waters were the most frequently used for all seasons. Rice fields have been widely used in October, but their importance has declined through the seasons as they become drier, with very few birds seen in this habitat during the month of May. The composition of the habitat is an important factor which influences the dynamics of colonial birds (Tourenq et al., 2004).

The distribution of these birds in different foraging environments could also depend on the species phenology. Chalabi -Belhadj (2008) reported that during the nesting season, the dispersion of Cattle Egrets becomes less loose and there has been a greater consolidation and concentration of individuals on pastures near nesting sites. Boukhtache (2010) added that during the nesting and incubation (April-May -June), the number of Cattle Egrets decreases in feeding grounds because most individuals are concentrated in the vicinity of breeding sites. In any case, the Cattle Egrets successfully exploit the different types of feed environment (Siegfried, 1978; Mora and Miller, 1998), especially the agroecosystems, where they collect a large number of preys. These consist mainly of pests (Mohammedi and Doumandji, 2013). However, the impact of predation of Cattle Egret on wildlife farmland studied is not only important, but also beneficial to crops in place.

\section{REFERENCES}

Abulude, O., Ogunkoya, M., Osadare, B., 2005. Nutrient status of meat content of Cattle Egret (Bubulcus ibis) in Nigeria. Journal of Food Technology, 3(4): 498-501 
Arendt, W.J., 1998. Range expansion of Cattle Egret (Bubulcus ibis) in the Greater Caribbean basin. Colonial Waterbirds, 11(2): 252-262

Benton, T.G., Vickery, J.A., Wilson J.D., 2003. Farmland biodiversity: is habitat heterogeneity the key? Trends. Ecol.Evol. 18: 182-88.

Bersonnet, C., Froissard, D., Lemesle B., 2009. Impact écologique de l'insertion de Miscanthus giganteus et de Switchgrass Panicum virgatum en Indre-et-Loire À travers les populations de carabes. Expérience pilote pour la région Centre. CPERCE, 37p.

Blondel, J., 1979. Biogéographie et écologie. Ed, Masson, Paris, 173 p.

Boukhemza M., Doumandji S., Voisin C. et Voisin J.F., 2000. Disponibilités en ressources alimentaires et leur utilisation par le héron garde bœuf en kabylie (Algérie). Revue d'écologie (terre et vie), 55: 361-381.

Boukhemza, M., Doumandji, S., Voisin, C., Voisin, J.F., 2004. Comparative utilization pattern of trophic resources by White storks Ciconia ciconia and Cattle egrets Bubulcus ibis in Kabylia (Algéria). Terre et Vie (Rev. Ecol.), 59: 559-580.

Boukhtache, N. 2010. Contribution à l'étude de la niche écologique de la Cigogne blanche Ciconiaciconia L., 1758 (Aves, Ciconiidae) et du Héron garde-boeufsBubulcus ibis L, 1758 (Aves, Ardeidae) dans la région de Batna. Thèse de magister, Université El Hadj Lakhdar de Batna, Algérie, 192p.

Bredin, D., 1984. Régime alimentaire du héron garde bœuf à la limite de son expansion récente. Revue d'écologie (terre et vie), 39: 431-445.

Burns, E.C. et Chapin, J.B., 1969. Arthropods in the diet of the Cattle Egret (Bubulcus ibis) in Southern Louisiana. J. Econ. Entomol, 62 (6): 736 - 738.

Chalabi-Belhadj, G., 2008. Contribution à l'étude des exigences écologiques des Ardeirdae et de l'Ibis falcinelle Plegadis falcinellus dans le complexe des zones humides d'El Kala (Algérie). Thèse doctorat, Inst. Nat. Agro., El Harrach. (Alger), 195p.

Clere, E. et Bretagnole, V., 2001. Disponibilité alimentaire pour les oiseaux en milieu agricole : Biomasse et diversité des arthropodes capturés par la méthode des potspièges. Rev. Ecol. (Terre Vie), 56: 275 - 297.

Craufurd, R.Q., 1965. Notes on the ecology of the Cattle Egret Ardeola ibis at Rokupr, Sierra Leone. Ibis, 108: 411-418.

Cusson, M., 2006. Le reboisement des friches. Impacts sur la faune et mesures de mitigation envisageables. Ministère des Ressources naturelles et de la Faune. Direction du développement de la faune. Québec, 48 pp.

Dajoz, R., 1985. Précis d'écologie. Ed. Bordas, Paris, 505p.

Dajoz, R., 2002. Les coléoptères carabidés et ténébrionidés : écologie et biologie, Paris, lavoisier, 522p.

Debras, J.F., Dussaud, A., Rieux, R. et Thierry D., 2007. Recherches prospectives sur le rôle " source » des haies en Production Fruitière Intégrée, le cas des Perce oreilles : Forficula auricularia L. et Forficula pubescens Gené. Comptes Rendus de L'Académie des Sciences, C.R.Biologies, 330(9): 664-667.

Dorst, J., 1971. La vie des oiseaux. Ed. Bordas, Paris et Montréal, T. I. 11: 382.

Doumandji, S., Benkouider, M., Bakkar, H., Mertad, A., Biche, M ; Harizia, A. et Koudour, A., 1988. Recensement hivernal des oiseaux d'eau dans l'ouest algérien en janvier 1988. Ann. Inst. Nat. Agro., El Harrach. 12(2): 99-119.

Doumandji, S., Doumandji-Mitiche, B. et Hamadache, H., 1992. Place des orthoptères en milieux agricoles dans le régime alimentaire de B.ibis Linné à Draa El Mizan en Grande Kabylie (Algérie), Mediterraneanfaculty of Landboww, Gent University, Belgium, 57(3a): 675-678. 
Doumandji, S., Harizia, M., Doumandji-Mitiche, B., Ait Mouloud S.K., 1993. Régime alimentaire de B.ibis Linné en milieux agricoles dans la région de Chlef (Algérie),Mediterranean faculty of Landboww, Gent University, Belgium, 58(2a): 365-372.

Duxbury, W.R., 1963. Food of nesting Cattle Egret and Reed Cormorant. Ostrich. 34: 110.

Etchecopar, R.D. et Hue, F., 1964. Les oiseaux du Nord de l'Afrique, de la mer rouge aux canaries. Ed. Boubée\&Cie, Paris VIe, 608 p.

Fasola, M., Rubolini, D., Enrico Merli, E., Boncompagni-Bressan, E.U., 2010. Long-term trends of heron and egret populations in Italy, and the effects of climate, humaninduced mortality, and habitat on population dynamics. Popul Ecol., 52: 59-72.

Filali, A. et Doumandji, S., 2007. Aperçu sur la pace des insectes dans le régime alimentaire du Héron garde-bœufs Bubulcus ibis (Linné, 1758) (Aves, Ardeidae) dans la région de Azzaba (Skikda, est-algérien). Ornithologia algirica, I (1): 1-10.

Fogarty, M.D. et Hetrick, W.M., 1973. Summer food of Cattle Egret in Nortrh Central Florida. Auk., 90: 268-280

Franchimont, J., 1986. Les lieux d'alimentation du Héron garde-bœufs Bubulcus ibis dans le nord-ouest marocain. Aves., 23(4): 216-224.

Frederick, P.C. et Mc Gehee, S.M., 1994. Wading bird use of wastewater treatment wetlands in central Florida, USA, Colonial waterbirds, 17: 50-59

Frontier, S., 1983. L'échantillonnage de la diversité spécifique. In Statégie d'échantillonnage en écologie, Frontier et Masson édit., Paris (Coll. D'Ecologie), XVIII + 494 p.

Frouz, J., 1999. Reconstruction of soil biota communities on post mining heaps with forest reclaimation and their role for soil formation. Ochrana prirody, 54: 157-159

Fujoka, M, 1985. Food delivery and sibling competition in experimentally even-aged broods of the Cattle Egrets, Bihavioral ecology and socio-biology, 17: 67-74.

Geroudet, P., 1978. Grands échassiers, Gallinacés, Râles d'Europe. Delachaux et Niestlé, Neuchâtel, Lausanne, Paris, 429 p.

Grubb, T. C., 1976. Adaptiveness of foraging in the Cattle Egret. Wilson Bull. 88: 145-148.

Hafner, H., 1980. Etude écologique des colonies des hérons arboricoles (Egretta g. garzetta L., Ardeola r. ralloïdes Scop., Ardeola ibis L., Nycticorax n. nycticorax L.) en Camargue. Bonn. Zool. Beiträge, 31: 249-287.

Heatwole, H., 1965. Some aspects of the association of Cattle egrets with Cattle. Animal Behaviour, 13(1): 79-83.

Ikeda, S., 1956. On the food habits of the Indian Cattle egret (Bubulcus ibis coromandus). Japanese J. Appl. Zool., 2: 83-86.

Jenni, D.A., 1969. A study of the ecology of four species of herons during the breeding season at Lake Alice, Alachua County, Florida. Ecological Monographs, 39: $243-$ 270.

Jenni, D.A., 1973. Regional variation in the food of nestling cattle egrets. Auk, 90: 821-826.

Joshi, P. et Shrivastava, V.K., 2012. Breeding biology and nest site selection of cattle Egrets (Bubulcus ibis) in Tawa reservoir and surrounding area of Hoshangabad District (M.P). Asian J. Exp.Biol.Sci., 3(3). 525-530

Lombardini, K., Bennett, R.E. et Tourenq, Ch., 2001. Foraging success and foraging habitat use by Cattle egrets and little egrets in the Camargue, France. The Condor, 103: 3844.

Lowe, K.W. in Gogger, H. G., Gould, E., Forshaw, J., Mc Kay, G., Zweifel, R. G., Kishner, D., 1994. Hérons et espèces voisines. Encyclopédie des animaux, Mammifères, Oiseaux, Réptiles et Amphibiens. Ed. Bordas, Paris, 687 p. 
Mckilligan, N., 1984. The Food and Feeding Ecology of the Cattle Egret, Ardeola ibis, When Nesting in South-East Queensland. Australian Wildlife Research, 11(1): 133-144.

Mckilligan, N., 2005. Herons, Egrets and Bitterns: their biology and conservation in Australia, CSIRO publishing, 144p.

Mohammedi, A. et Doumandji, S., 2013. Le statut des proies de Bubulcus ibis dans la région de Chlef, Rev. Écol. (Terre et Vie), 68: 283-289

Mora, M.A. et Miller J.M., 1998. Foraging flights, reproductive success and organochlorine contaminants in Cattle Egrets nesting in a residential area of Bryan, Texas. The Texas Journal of Science, 50(3).

Parasharya, B.M., Dodia, J.F., Mathew, K.L., Yadav, D.N., 1994. Natural regulation of white grub (Holotrichiasp:Scarabidae) by birds in agroecosystem., J. Biosci., 19(4): 381389.

Roth, M., 1972. Les pièges à eau colorés, utilisés comme pots de Barber. Extrait de la Reoue de Zoologie agricole etde Pathologie vigétule. Services Scientifiques Centraux de 1 'ORSTOM - Bondy. pp: 78-83

Ruiz, X., 1985. An analysis of the diet of Cattle egret in the Ebro delta, Spain. Ardea., 73: 4960.

Ruiz, X. et Jover, L., 1981. Sobre la alimentación otoñal de la garcillabueyera Bubulcus ibis (L.) en el delta del Ebro, Tarragona, España. Publicaciones del Departamento de Zoología de la Universidad de Barcelona, 6: 65-72.

Salmi, R., Doumandji, S. et Si Bachir, A., 2002. Variations mensuelles du régime alimentaire du Héron garde-boeufs (Bubulcus ibis) dans la région de Béjaïa. Rev. Ornithologia algirica, II(1): $50-55$.

Scott, D., 1984. The feeding success of cattle egrets in flocks, Animal Behavior, 32(4): 10891100.

Seedikkoya, K., Azeez, P.A., Shukkur, E.A.A., 2005. Cattle Egret Bubulcus ibis habitat use and association with cattle, Short notes, Forktail, 21: 174-176.

Seedikkoya, K., Azeez, P.A. et Shukkur, E.A.A., 2007. Cattle Egret as biocontrol agent, Zoos print Journal, 22(10): 2864-2866.

Setbel, S., 2008. Expansion du Héron garde-boeufs en Algérie : processus, problèmes et solutions. Thèse de Doctorat en sciences agronomiques. INA. El Harrach. 246p.

Setbel, S., Doumandji, S., Boukhamza, M., 2004. Contribution à l'étude du régime alimentaire du Héron garde-bœufs Bubulcus ibis dans un nouveau site de nidification à Boudouaou (Est- Mitidja). Alauda, 72(3): 193-200.

Sharah H.A., Ali E.A., Mohammed, I.D., 2008. The Feeding Behavior of the Cattle Egrets, (Bubulcus ibis L.) in Northeastern Arid Zone of Nigeria, Journal of agriculture \& social sciences, 4: 6-12.

Si Bachir, A., Hafner, H., Tourenq, J.N., Doumandji, S., Leck, S., 2001. Diet of adult Cattle Egrets Bubulcus ibis in a new North African colony (Soummam, kabylie, Algeria): Taxonomic composition and seasonal variability, Ardeola, 48(2): 217-223.

Siegfried, W.R., 1966. On the food of nestling Cattle Egret. Ostrish, 37: 219-220

Siegfried, W. R., 1971. Feeding activity of the Cattle Egrets. Ardea, pp: 38-46.

Siegfried, W.R., 1978. Habitat and the modern range expansion of the Cattle Egret. Nat. Audubon. Soc., New York, Res. Rep., 7: 315-324.

Spellerberg, I.F. 1993. Monitoring Ecological Change. Cambridge University Press. pp. 334.

Tourenq, C., Benhamou, S., Sadoul, N., Sandoz, A., Mesleard, F., Martin, J.L., Hafner H., 2004. Spatial relationships between tree-nesting heron colonies and rice fields in the camargue, France, The Auk, 121(1): 192-201 
Vasquez Torres, M.Y. and Marquez Mayaudon, M.C., 1972. Algunosaspectos ecologicos y la alimentacion de la 'Garzagarrapatera"' Bubulcus ibis ibis (Linneo) en la region de La Mancha. Actopan, Veracruz. An. Inst. biol. nat. Univ. Mexico, 43 ser. Zool., 1: 89-116.

Voisin, C., 1979. Les populations arboricoles d'Ardéidés dans le Delta du Rhône de 1968 à 1977 : Evolution des effectifs et période de reproduction. Alauda, 47(3): 151-156.

Voisin, C., 1991. The Herons of Europe. T. \& A.D. Poyser, Academy Press, London, 364p. 